\title{
JOSEP MANUEL UDINA I COBO, IN MEMORIAM
}

\author{
Jaume Mensa Valls \\ Universitat Autònoma de Barcelona
}

Josep Manuel Udina falleció en Barcelona, el día 7 de noviembre de 2014, dos días antes de cumplir 75 años (había nacido en Barcelona, el día 9 de noviembre de 1939), tras varias intervenciones quirúrgicas y algunos meses de enfermedad.

El profesor Josep Manuel Udina fue miembro fundador de la SOFIME, formó parte de su Consejo directivo y solía participar con entusiasmo en todas las actividades de la sociedad. También pertenecía al Consejo de redacción de la Revista Española de Filosofía Medieval y escribió varios artículos para la revista. Con motivo de su jubilación como profesor de Filosofía en la Universitat Autònoma de Barcelona, en el año 2010, nuestra revista editó una breve nota biográfica, con sus principales publicaciones. ${ }^{1}$

Después de cursar el bachillerato en los jesuitas de Sarrià, Josep Manuel Udina estudió Filosofía y Teología. Su tesis de licenciatura en filosofía, dirigida por el profesor Alfonso Álvarez Bolado, estuvo dedicada a la Fenomenología del espíritu de Hegel (Universitat de Barcelona, 1966, 353 páginas); y la de doctorado, dirigida por Miquel Siguan, a Ernst Bloch: La constitución utópica de lo humano. Introducción y anotaciones críticas a la filosofía de Ernst Bloch (Universitat de Barcelona, 1976, 824 páginas).

Josep Manuel Udina dedicó prácticamente toda su vida académica y profesional, es decir 38 años, a la Universitat Autònoma de Barcelona, al Departamento de Filosofía concretamente. Impartió diversas materias: un seminario cada dos años sobre Hegel, un curso sobre Filosofía española y, a partir del curso 1978-1979 especialmente la Historia de la Filosofía Medieval (I, II y III). También profesó cursos de doctorado sobre Hegel, Bloch, Anselmo de Canterbury y otros autores. En la UAB era un profesor muy respetado y admirado por sus colegas y alumnos. Dirigió varias tesis, la última (sobre Marcelino Menéndez y Pelayo) fue defendida en 2012, justo antes de ser intervenido por primera vez. Estuvo pues activo, ejerciendo su magisterio hasta el último momento. ${ }^{2}$ En junio de 2010 pronunció su Darrera lliçó magistral: l'ésser mai no acabat que som (Universitat Autònoma de Barcelona, 2010, 33 páginas). Ya jubilado, escribió junto con Pere Led y el dibujante Toni Batllori, el exitoso libro Hic et nunc. Aquí i ara ... encara parlem llatí (Barcelona, La Vanguardia, 2013, 217 páginas), traducido recientemente al castellano (Hic et nunc. Aquí y ahora... seguimos hablando latín, Madrid, Gedisa, 2015, 222 páginas).

Sus principales estudios están dedicados a autores o temas medievales: Agustín y el agustinismo político, Avicena, Averroes, Duns Escoto, la relación entre fe y razón, la doctrina de la creación, las pruebas de la existencia de Dios, el diálogo interreligioso, pero su verdadera

1 El lector interesado hallará indicaciones sobre sus publicaciones en mi nota «Josep Manuel Udina i Cobo, medievalista», en Revista española de filosofía medieval, 18 (2011) 239-242.

2 Véase Udina, J. M., «La enseñanza de la historia de la filosofía medieval: una experiencia de veinticinco años», en Revista española de filosofía medieval, 10 (2003) 199-206. 
especialidad era Anselmo de Canterbury y Nicolás de Cusa. Aparte de dedicarles diversos artículos, tradujo al catalán, entre otras obras, sus Per què Déu es va fer home (Barcelona, Proa, 1992, 218 páginas) y La recerca de Déu i altres escrits (Barcelona, Proa, 2000, 230 páginas).

Sus clases (y también sus publicaciones) reflejaban bien su profundo conocimiento de la historia de la filosofía, una aguda capacidad crítica y una clara vocación didáctica. Tenía una rara habilidad para encontrar el justo punto crítico para valorar una idea, un libro o un autor. Sus opiniones eran siempre muy originales, meditadas, sinceras. Quizás por esto, los estudiantes y los colegas buscaban frecuentemente consejo en él.

Todos los que le conocimos, como profesor, maestro, colega y amigo sabemos bien que era un profesor brillante, una persona responsable y trabajadora, y un amigo fiel y entregado, y por esto añorado. Pasó sus últimos días, como había pasado el resto de su vida: lúcido, con un inteligente sentido del humor, sereno, al lado de Empar y con el calor familiar de sus tres hijos y sus respectivas familias.

Jaume.mensa@uab.cat 